\title{
LITERATURA VIVA OU VIDA NA LITERATURA: A TORRE DE MARFIM DA PRESENÇA COMO ALVO PREFERIDO DOS NEORREALISTAS
}

\author{
LITERATURE LIVE OR LIFE IN LITERATURE: THE \\ IVORY TOWER OF PRESENÇA AS FAVOURITE TARGET \\ OF SOCIAL REALISM
}

Fernando Teixeira Batista*

RESUMO: Este texto apresenta a querela que, nos anos 30 e 40 do século XX, os escritores e críticos próximos da revista Presença, revista associada ao Segundo Modernismo Português, mantiveram com o grupo de intelectuais que visava lançar as bases de um novo movimento cultural, o Neorrealismo. Convocando textos publicados na Presença e textos publicados em diversos órgãos de difusão da nova tendência realista, expomos o confronto de conceções e funções da arte e da literatura, bem como o papel social dos escritores.

Palavras-chave: Modernismo, Presença, Neorrealismo.

Aвstract: This paper presents the squabble that, during the 30 s and 40 s of the twentieth century, writers and critics close to the literary magazine Presença, associated with the Second Portuguese Modernism, maintained with the group of intellectuals who sought to lay the foundations of a new cultural movement, Neorealism. Calling texts published in Presença and other texts published in several broadcasting agencies of the new realistic trend, we expose the clash of conceptions and functions of art and literature, as well as the social role of the writers.

KeYwords: Modernism, Presença, Neorealism.

"Doutor em Literatura Portuguesa pela Faculdade de Letras da Universidade do Porto (Portugal). 
Em 1936, a conferência que Alves Redol pronunciou no Grémio Artístico Vilafranquense, com o título Arte, defendendo a arte útil e inspirada em Plekhanov sobre as teses de Théophile Gautier sobre a inutilidade da Arte, suscitou fortes reações dos colaboradores da revista Presença e deu início a uma querela sobre conceções e funções da arte que viria a prolongar-se pelos restantes anos da década e pelos anos 40. De um lado, os jovens escritores e críticos da geração neorrealista - influenciados pela literatura nordestina brasileira, pelo realismo social norte-americano e por teóricos e escritores russos (como Plekhanov ou Gorki) e franceses (como Friedmann, Lefebvre ou Gutermann) e pelos escritos que lhes chegavam de Marx e Engels; do outro, os críticos e escritores afetos sobretudo à revista Presença. O facto de muitos neorrealistas e presencistas terem sido escritores e críticos poderá ter ajudado a alimentar a querela teórica, que em nada terá prejudicado o movimento neorrealista, o qual precisava de se afirmar, de expor as suas conceções e de estabelecer pressupostos teóricos que, de algum modo, pudessem orientar e acompanhar a produção literária.

As posições dos presencistas seriam sobretudo veiculadas por nomes maiores do Segundo Modernismo, como José Régio, Gaspar Simões e Casais Monteiro, conquanto este último apenas se tivesse juntado aos anteriores, fundadores da revista, em 1931, depois da saída de um outro fundador, Branquinho da Fonseca. José Régio seria, todavia, "o pólo dominante e aglutinador de todo o grupo, o verdadeiro sol daquele pequeno sistema planetário", como considera David Mourão-Ferreira (1993, p. 7).

Quando surge a querela entre estes grupos, do seio da Presença, já haviam saído alguns dissidentes - Miguel Torga, Edmundo Bettencourt e Branquinho da Fonseca - os quais teriam ido contra a própria bandeira da arte pela arte (ainda que os presencistas explicitamente não a defendessem) e da inutilidade da arte. O surgimento de revistas como a Manifesto (em Coimbra, precisamente em 1936), dirigida pelo dissidente Miguel Torga e por Albano Nogueira, constituiria também, de algum modo, já uma contestação da Presença.

As posições dos novos escritores seriam expressas em ensaios teóricos e recensões críticas assinados por nomes como Mário Dionísio, Joaquim Namorado, Bento de Jesus Caraça, Fernando Lopes Graça ou Manuel Campos Lima e veiculadas por diversos jornais e revistas da época: O Diabo, Sol Nascente, Alvorada, Seara Nova, O Globo, Gládio, Gleba, Altitude, Sintese, Pensamento e Vértice. A par dos jornais e revistas, o movimento procurou operacionalizar um aparelho difusor das suas obras e ideias: coleções de livros (Novo Cancioneiro e Novos Prosadores), colaboração regular na imprensa regional, organização de eventos diversos. No fundo, a criação deste aparelho cultural evidenciava que a cultura era considerada, no contexto da movimentação neorrealista, uma questão central e que se procurava aproximá-la das massas populares.

Os escritores e colaboradores da Presença, desde 1927- quando surgiu a revista - vinham considerando a originalidade, 
a sinceridade e o individualismo conceitos basilares na criação artística. $\mathrm{O}$ artigo de abertura do $\mathrm{n}^{\circ} 1$ da revista, no qual José Régio critica a falta de originalidade e sinceridade de uma boa parte da literatura contemporânea, abre com as seguintes frases: "Em Arte, é vivo tudo o que é original. É original tudo o que provém da parte mais virgem, mais verdadeira e mais íntima duma personalidade artística". Para Régio a literatura viva era "aquela em que o artista insuflou a sua própria vida” (1927, pp. 1-2).

A voz que a literatura presencista vinha fazendo ouvir era, pois, tendencialmente a de um eu individual, cuja expressão assentava num conhecimento intuitivo e perspetivava uma receção semelhante. Uma literatura "nem humana, nem desumana - individualista", como defendia Gaspar Simões no ano seguinte ao da criação da revista (1928, p. 2). José Régio escreveria precisamente no ano anterior ao da conferência de Redol: "A arte é expressão, sugestão, ou representação do mundo (interior e exterior) através dum temperamento próprio, dum conhecimento pessoal, duma alma individualizada" (1935, p. 12).

Nesta altura, muitos dos jovens escritores portugueses, que iam conhecendo Gorki, Jorge Amado, Lins do Rego, Graciliano Ramos, Erico Veríssimo, Hemingway, Caldwel, Steinbeck, entre outros, depois de se terem sentido atraídos pela irreverência e dinamismo da Presença - recordo que alguns escritores neorrealistas começaram a publicar nesta revista, como Fernando Namora, Joaquim Namorado, Cochofel, Ramos de Almeida e Mário Dionísio - seguiriam posteriormente estes ventos literários que começavam a chegar, no final dos anos 30 , ao ambiente coimbrão (até então dominado pela Presença) e os levariam a afastar-se de uma literatura que não respondia aos problemas do mundo e do homem coletivo e lhes despertaria, como diria Fernando Namora, o "desejo de manifestar (...) a sua adesão às classes oprimidas que eram chamadas ao despertar de uma consciência social" (1991, p. 207).

De facto, pode afirmar-se que o movimento neorrealista foi influenciado por algumas tendências literárias que, na Europa e nas Américas, mostravam afinidades ideológicas e mostravam não desconhecer os mais urgentes apelos do homem comum. No fundo, a superação do passado próximo da literatura portuguesa far-se-ia bebendo das tendências presentes que se iam difundindo em vários países do mundo. O neorrealismo deveria, pois, muito da sua identidade periodológica à sua condição transnacional.

Observe-se, no entanto, que o realismo crítico de escritores como Ferreira de Castro parece ser já uma forma de algum afastamento das tendências presencistas. Neste sentido, poder-se-á afirmar que o neorrealismo nasce de um entroncamento em que se disputam ou interdependem três vetores: o presencismo dissidente, o realismo crítico e a teorização do novo realismo ou realismo socialista, esta última influenciada pelas relações culturais internacionais (Sacramento, 1967, p. 67).

Os testemunhos teóricos defensores do "neo-realismo" - expressão usada pela primeira vez em 1938 por Joaquim Namorado no jornal O Diabo (Torres, 1977, p. 63) - foram dando conta, ao longo dos anos 30 e 40, de 
um programa que, apesar de manifestar considerável consistência, deu azo a diferentes interpretações.

O vaivém que existiu nestas décadas de 30 e 40 entre teoria e prática foi uma característica do movimento e defendido explicitamente por alguns jovens desta nova geração. Todavia, na realidade, a exposição teórica permitiu reflexões que não se confinavam a aspetos artísticos. Perceberam-se, de facto, algumas divergências culturais e ideológicas nessas discussões. Os argumentos destes jovens de 40 refletiam sobretudo uma conceção de literatura diferente da que vinha sendo a tendência presencista. Defendiam para a literatura compromissos e funções distintos dos que a geração anterior lhe reservara.

Deve, no entanto, salientar-se que entre neorrealistas e presencistas existiam algumas afinidades, sobretudo ao nível do recurso ao tradicional significado que a palavra literária possuíra em épocas pré-modernas. O segundo modernismo reivindicou uma $l i-$ teratura viva que, consideravam, desde o primeiro modernismo tinha ido desaparecendo, sobretudo em alguns escritores.

O que a geração do novo humanismo de 40 procurou foi acolher dialeticamente integrando e superando-a herança cultural. Escrevia nessa década o teórico neorrealista Rodrigo Soares: "Para nós, humanistas consequentes, o passado é digno de atento estudo (...). Não renegamos a cultura do passado; mas nada nos obriga a aceitá-la passivamente, sem a compreendermos e explicarmos" (1947, p. 8). Tendo em vista esta superação, a teoria neorrealista contestou sobretudo os aspetos de que discordavam dos movimentos com os quais tinham algumas afinidades. Por isso, as suas atenções viraram-se sobretudo para o realismo do séc. XIX e para esta literatura do segundo modernismo. A verdade é que, no plano da criação, há mais terreno comum aos presencistas e aos neorrealistas do que o plano teórico-crítico deixaria supor.

Apesar das consideráveis oposições, alguns neorrealistas verbalizam o reconhecimento do valor da Presença. Sobre as conquistas modernistas, em geral, as posições dos novos intelectuais foram divergentes, percebendo-se algumas vozes - a contracorrente de outras - elogiosas do modernismo e da Presença. De facto, conquanto advogassem a necessidade de ultrapassar a Presença em prol de uma nova estética, muitos reconhecem à revista um papel significativo no período modernista. ${ }^{1}$

Deve reconhecer-se, também, que o grupo presencista já vinha manifestando algum inconformismo relativamente a alguma literatura portuguesa das primeiras décadas do século. A nova geração humanista desejava, contudo, superar a literatura viva do segundo modernismo.

Verdadeiramente, o que se procurava era que o neorrealismo fosse uma síntese e uma superação da história literária, sobretudo, é verdade, das épocas que mais o influenciavam, as do realismo e do romantismo. Do realismo herdava-se sobretudo uma opção estética, do romantismo uma mentalidade

\footnotetext{
${ }^{1}$ Muitos dos novos teóricos e escritores reviam-se nas palavras de Mário Dionísio sobre os modernistas: "penso que a obra desses escritores teve a sua utilidade na evolução da nossa literatura, na criação da nossa literatura moderna", no entanto, "a determinada época literária sucede sempre uma antagónica” (1939, p. 1).
} 
revolucionária, do modernismo algumas conquistas estéticas ${ }^{2}$.

Privilegiando a intenção comunicativa de aspetos da vida social - que, devido à repressão, não podia concretizar-se noutras formas de comunicação não artística -, algumas obras, nos anos 40, resultaram em "formas primárias de literatura", como reconhece um membro da geração, Mário Sacramento (1967, p. 68), em meros depoimentos ideológicos ilustradores de teses, os quais foram usados pelos críticos do novo movimento (nomeadamente os presencistas) para, generalizando, atacar o neorrealismo.

Casais Monteiro criticaria nos anos $40 \mathrm{a}$ falta de subjetivismo individualista de alguns escritores, que procuravam um alegado realismo social: "Os escritores de intenções apenas moralistas ou pedagógicas, ou políticas, não arrancam a literatura dolorosamente de si próprios" (1948, p. 168). Os presencistas, em oposição à estética realista, defendiam que $\mathrm{a}$ arte satisfizesse a necessidade humana de emoções estéticas. Gaspar Simões, num texto também crítico do realismo e apologético da deformação da realidade como condição de criação artística, defendia que o "poder de impressionar esteticamente" apenas está reservado "à obra deformada (...), formada consoante uma visão pessoal dela" (1935, p. 9). Acrescentava: "o que importa (...) é fixar-se a imagem do mundo reflectido em nós

\footnotetext{
${ }^{2}$ Alexandre Pinheiro Torres considera os quatro primeiros autores do Novo Cancioneiro - Fernando Namora, Mário Dionísio, João José Cochofel e Joaquim Namorado os que teriam sido "mais capazes de, ao mesmo tempo, continuarem as conquistas estéticas do modernismo (...) e pô-las ao serviço de uma nova visão humana, mais próximo das realidades sociais" (1989, p. 61).
}

mesmos. A fixação desta imagem - eis o que me parece fundamental na arte moderna (idem: 11).

No entanto, na realidade, o que os presencistas contestavam era o conteúdo e o pragmatismo, os quais, de facto, iriam resultar numa forma que se distanciava da que preconizavam. Perspetivando o pragmatismo da comunicação literária, os neorrealistas não esqueceram a receção das obras nem a sua legibilidade. Teoricamente, O Diabo, que defendia uma cultura popular, desejava a formação do público e que este se elevasse ao nível da cultura, objetivo para o qual os escritores desejavam contribuir. Este era, no entanto, um desejo considerado por muitos como utópico, daí que diversas vozes neorrealistas desejassem uma literatura mais acessível ao povo concreto, pois só assim ele aderiria à literatura e poderia sofrer os seus efeitos. Esta posição, rejeitada também por muitos escritores neorrealistas, era criticada pelos presencistas. Casais Monteiro, por exemplo, criticava os que "preconizam uma cultura ao alcance das massas, (e) não entendem que estas devem ascender àquela, mas sim que a cultura desça até elas" (1937, p. 8).

Segundo os neorrealistas, o intelectual presencista queria manter-se na sua torre de marfim, alheado da realidade social, "acima das convulsões sociais, desumanizado, megalómano", escrevia Rui Gradim na Vértice (1948, p. 339). Os neorrealistas, em Portugal, encontraram na revista Presença o símbolo do inimigo principal do paradigma de intelectual em construção, ou seja, o letrado que se refugiava na torre de marfim, avesso à intervenção social. Neste sentido, os jovens 
neorrealistas acusavam os presencistas de não se empenharem na união de valores de arte e de humanidade; ${ }^{3}$ acusavam-nos de viverem pela e para a sua Arte. Estão muito distantes de, por exemplo, Romain Rolland, uma referência dos jovens neorrealistas, que escrevera: "Creio firmemente na Arte, não pela Arte mas pela vida” (apud Salema, 1982, p. 43).

O inconformismo, não apenas literário, foi uma característica do movimento neorrealista, o qual rejeitava as políticas económicas e culturais do país, a sua organização social, bem como a conceção artística, que não dava qualquer contributo para eventuais mudanças. Enquanto o modernismo privilegiara uma análise psicológica, a nova geração, não a excluindo, pretendia relacioná-la com a realidade social: "não pode haver uma capaz análise psicológica sem uma suficiente análise social", considerava Campos Lima (1948', p. 361).

Gaspar Simões, nos anos 30, num texto sobre o romance brasileiro, defendendo a perspetiva psicológica, criticou romancistas brasileiros por não serem psicólogos:

Graciliano Ramos afigurou-se-me, realmente, um dos raros romancistas novos do Brasil capazes de uma certa penetração e objectividade no estudo da psicologia das suas personagens. (...) Lins do Rêgo e Erico não convencem:

\footnotetext{
${ }^{3} \mathrm{O}$ presencista Gaspar Simões não os negava, quando escrevia: "A arte não é, efectivamente, uma actividade social (...). Todo o artista é um produto espontâneo, um organismo predestinado, mágico" (apud Rocha, 1985, p. 402). José Régio também escrevia na Presença: "como arte, qualquer obra de arte não responde senão a um problema de ordem estética; e a resposta é a própria obra realizada" (1935, p. 12).
}

Lins do Rêgo é um belo poeta da adolescência: não é um psicólogo. Erico Veríssimo é um belo poeta da feminilidade, não é um psicólogo (SIMÕES, 1939, p. 58).

Nesses anos 30, vários escritores constatavam que a literatura se encontrava distante dos problemas do povo, mesmo alguns daqueles que não viriam a ser identificados pela crítica como escritores do movimento neorrealista. Rodrigues Miguéis lamentava que "todas as inquietações do nosso tempo, tão rico em motivos, tudo o que é essencial, está fora (ou quasi) da nossa literatura" (apud Trindade, 2004, p. 217).

Algumas das principais críticas que os jovens d' O Diabo e do Sol Nascente faziam aos presencistas são reconhecidas ironicamente num texto publicado na Presença ainda nos anos 30 por José Régio: "ensimesmento estéril, entaipamento na tal Torre, auto-estrangulamento na personalidadezinha inchada e particular, etc.". Acrescenta: "Não sou tão imodesto que julgue o único alvo dessa tentativa de desautorização! Dirige-se ela contra todo um grupo de homens que, pelo visto, fazem sombra a um já considerável número de generosas almas" (1939, p. 61).

O neorrealismo, no entanto, mais do que uma escola, conquanto viesse a criar uma tendência literária, começou por ser uma posição do pensador, do artista e do escritor. A obra de cultura seria, pois, "toda a realização destinada a dar a conhecer o mundo real na sua totalidade" (idem: 11). Tratava-se de um movimento, imbuído de uma certa "consciência" e uma certa "mentalidade", que se quis "político-culturalmente totalizante" 
(Pita, 2002, p. 9). Aproximaram a psicologia, a sociologia, a história, a política, a economia da literatura. Pretenderam transmitir culturalmente uma vasta visão do mundo.

É verdade que as diferenças entre escritores presencistas e neorrealistas foram quase sempre verbalizadas invocando argumentos do campo literário: discutiam-se explicitamente conceções de literatura. Parecia que o que estava em questão seria saber até que ponto se podiam conciliar os interesses sociais coletivos com os chamados interesses da literatura. No entanto, a discussão teórica verificou-se mais ao nível de questões filosófico-ideológicas do que ao nível temático ou estilístico-literário, até porque, nestes aspetos, não havia sequer consensos entre os neorrealistas, parecendo apenas consensual a necessidade de uma literatura realista. A literatura (também ela perspetivada historicamente nas suas relações dialéticas), em rutura com a filosofia idealista, procurou sobretudo, como defendia Lukács, "estabelecer firmemente a prioridade da realidade objetiva comum" (1978, p. 160). Neste sentido, o que realmente se discutia era a necessidade de aproximar a literatura da verdade da vida e de potenciar seu conhecimento total ou a necessidade de manter a literatura como uma superestrutura autónoma não refletindo nem projetando qualquer reflexo na sociedade, pouco viva, portanto.

Na Presença, Casais Monteiro, a propósito de um romance de Lins do Rêgo, criticava os romances que expunham preocupações económico-sociais. Lê-se: "Lins do Rêgo mostra-se sêco, mais memorialista e historiador do que romancista, "traindo" as suas personagens, e diminuindo-as, pela preocupação de mostrar o esquema dos imperativos económico-sociais que as determinam" (1937, p. 8).

A preocupação com a realidade socioeconómica e com a sua consciencialização pelas massas populares, levou a uma "nova proposta: falar pelos desvalidos" (Coelho, 2007, p. 175). Isto conduziria à teorização sobre a explicitação da mensagem literária, sobre a qual a geração neorrealista não mostrou consensos. De modo geral, os teóricos do movimento pretendiam uma mensagem de fácil compreensão pelo povo, enquanto os escritores do mesmo movimento não queriam prescindir dos valores estéticos das suas obras.

O neorrealismo desejava uma nova cultura viva que unisse teoria e prática e que fosse útil ao povo português. Em 1939, escrevia Bento de Jesus Caraça, n`O Diabo, sobre o pensamento moderno e a nova cultura:

O traçado de um moderno pensamento português tem de obedecer a uma visão contemporânea e universalista que penetre na realidade económica e social da nação e dela extraia um conhecimento geral das determinantes que condicionam a vida de todos os cidadãos. Uma nova cultura nacional tem de ser o tratado teórico e prático de uma nova interpretação e de uma nova ética. Uma nova cultura nacional tem de ser o conjunto vivo de ideias, ligado inteiramente a todas as dificuldades da existência material da nação. Um conjunto de ideias que procure ser útil aos portugueses, como homens e como cidadãos. (CARAÇA, 1939, p. 1). 
No fundo, o que separava verdadeiramente presencistas e neorrealistas era o entendimento da finalidade da arte, a transferência de um plano psicológico para um plano social, resultando daí a passagem de uma polaridade estética para uma propensão ética da linguagem.

Embora a temática social pudesse ser vasta e qualquer assunto pudesse ser neorrealista, defendia-se teoricamente a importância de se "exprimir a vida e a intensidade humana de personagens num dado meio, estabelecendo os determinantes das suas acções", escrevia Rui Feijó na Seara Nova (1943, p. 319). A opção pelo realismo era consensual, todavia isso não acarretava a submissão a temas concretos, ainda que os temas sociais parecessem inevitáveis.

Segundo este novo realismo, urgia denunciar os dramas do povo e mostrar-lhe que poderia contribuir para a alteração da realidade social. O povo deixava de ser perspetivado como objeto da História, condição que o realismo oitocentista lhe reservara, e passava a sujeito da História, papel que o neorrealismo lhe atribui.

À rejeição do formalismo e às dificuldades da comunicação poética, juntavam-se a viabilidade da representação realista, a propensão documental da narrativa e a sua adequação a uma metodologia de análise social de inspiração dialética como principais fatores que levaram os jovens humanistas a invocar teoricamente a narrativa como género indicado para a criação literária neorrealista (Reis, 1983, p. 215).

Mário Dionísio, nos anos 30, cotejando poesia e romance, reconhecia o carácter mais documentado e intelectual da comunicação romanesca, que a nova cultura queria privilegiar:

A poesia dá-nos uma afirmação que muitas vezes compreendemos mais sensivelmente do que inteligentemente.. (...) Enquanto num poema se nos afirma directamente é, num romance afirma-se-nos é de uma forma talvez mais indirecta mas mais documentada: - é por isto, não é por aquilo. (DIONÍSIO, 1937, 3).

O pragmatismo desta comunicação romanesca conduziria a preferências temáticas e a processos literários distintos dos do realismo oitocentista: enquanto o realismo do séc. XIX se ocupara do modo de vida e das preocupações da burguesia, o neorrealismo procurará os temas que se ligam ao proletariado e à sua condição económica: pobreza, posse de terra, opressão, conflito social, alienação e consciência de classe; enquanto o realismo oitocentista fotografou a realidade como um facto, o neorrealismo procurava mostrar fenómenos sociais que pudessem potenciar a compreensão da essência da realidade como um todo dinâmico.

As preferências temáticas neorrealistas permitiriam inferir que os novos escritores procuravam dirigir-se ao povo (considerariam que só a luta de classes poderia conduzir a uma profunda mudança) e não à burguesia, esperando convertê-la, como haviam esperado os realistas do século anterior. Neste aspeto, o neorrealismo inspirava-se mais no romantismo social do que no realismo.

Algumas técnicas literárias das primeiras obras neorrealistas estavam em sintonia 
com o que os teóricos de inspiração materialista sustentavam: "a forma artística é infiel às singularidades para poder ser fiel à realidade tomada em seu conjunto", recordando palavras de Lukács (1978, p. 275). Neste sentido, qualquer extremidade seria falsa: a acentuação na singularidade cai no subjetivismo; a acentuação na universalidade cai no dogmatismo; é, pois, a particularidade que inter-relaciona singularidade e universalidade (idem: 159). Segundo uma perspetiva materialista dialética, toda a singularidade se encontra de algum modo em relação com a universalidade. Esta perspetiva que relaciona a vida dos indivíduos com a vida social é acolhida com simpatia pela nova geração neorrealista portuguesa.

Perspetivando a realidade como um processo, no qual o homem intervém e do qual o escritor não se devia alhear, a teorização neorrealista colocou no centro da discussão o papel do escritor e as funções da literatura. Isto terá contribuído para que o neorrealismo, como considera Eduardo Lourenço, se definisse sobretudo pela "afirmação de um novo papel atribuído ao escritor e à coisa escrita" (1982, p. 2).

O repto lançado, em campo teórico, aos novos intelectuais apelava ao compromisso com os homens e com a sociedade; deste modo, os intelectuais deviam perspetivar uma possível transformação do mundo, melhorando-o e humanizando-o. Deveriam combater por uma arte do mundo a que pertenciam, "por uma arte de largo sentido humano", como considerava Joaquim Namorado nos anos 40 (1944, p. 14). Nesta mesma década, Rui Feijó resumiria desta forma a "função máxima do escritor neo-realista: dar vida com o máximo de realidade" (1943, p. 319).

A luta neorrealista ia, pois, no sentido de procurar direcionar a literatura para o povo e, assim, para além de potenciar uma real comunicação e de fazer chegar uma mensagem de consciencialização - que o contexto impunha-, poderia, esperavam eles, potenciar o alargamento e o desenvolvimento do público leitor de obras literárias.

Já em 1935, Amorim de Carvalho defendia a necessidade de se produzir "arte para o povo e pelo povo" (1935, p. 2), arte que pudesse intervir no mundo e conferisse à sua mensagem um caráter pedagógico. Escrevia em 1940 Campos Lima: "A arte que pedimos, pedimo-la para todos: não a queremos para regalo de uma nobreza. Cuidamos que com esforço paciente e interessado dos artistas, eles podem realizar obras que todos compreendam e a todos sirvam porque a todos eduquem" (1940, p. 1).

Os jovens de 1930 e 40 pediam, então, uma literatura ética e pedagógica, mais comprometida com a transformação social, o que implicaria uma busca da desalienação do homem. Através da literatura, numa perspetiva otimista, o que os escritores desejavam mudar era o homem, este é que poderia transformar o mundo.

Esta conceção de artistas como engenheiros de almas provocara reações dos presencistas, os quais consideravam que a arte neorrealista seria usada como arauto de ideologias. Este facto não é desmentido por Ramos de Almeida nos anos 40, que considera mesmo que a arte pode ser ativante de 
revoluções históricas: "a arte é (arauto), grito, voz expressiva daquelas forças silenciosas que dormem nas entranhas mais recônditas da Vida Social. Eis porque a Arte (...) vale muito mais como ideologia activante das revoluções históricas do que as próprias doutrinas filosóficas que as tentam explicar" (1945, p. 27).

É por esta razão que José Régio, em 1940, criticava, na Presença, a "tentativa de arregimentação dos artistas para fins extra-artísticos, empreendida por alguns pseudo-críticos ou pseudo-artistas do momento que passa" (1940, p. 121).

Rejeitando estas críticas, que os acusavam de não preservarem a pureza da arte ao quererem condicioná-la a certas ideologias, os neorrealistas consideravam que a arte pura não existia, pois toda ela mantinha relações com conceções que ultrapassam o campo estritamente artístico. Assim, tão comprometida com uma filosofia - idealista ou materialista - era a arte modernista como a arte neorrealista, ambas expressando também certas ideologias, uma a dominante, outra, segundo os novos realistas, a ascendente.

Alguns neorrealistas considerariam mesmo o modernismo como uma "doença infantil”, palavras de Mário Dionísio (1949: 369) ou uma "escola decadentista", na opinião de Carlos Relvas (1946, p. 197). Alves Redol defendia:

A arte pela arte é uma ideia tão extravagante em nossos tempos como a de riqueza pela riqueza, ou de ciência pela ciência. (...) Todos os assuntos devem servir em proveito do homem, se não querem ser uma vã e ociosa ocupação; a riqueza existe para que toda a humanidade goze; a ciência para guia do homem; $a$ arte deve servir também para algum proveito essencial e não deve ser apenas um prazer estéril. (...) A arte deve contribuir para o desenvolvimento da consciência e para melhorar a ordem social (apud Torres, 1977: 36-37).

Esta conceção levaria alguns neorrealistas a considerar a arte modernista como "arte castrada", cito Armando Martins na Sol Nascente (1937, p. 12), a qual nem projetava os sentimentos de uma sociedade nem expressava qualquer pensamento que revelasse fraternidade e solidariedade para com as necessidades dos homens. Manuel Campos Lima criticava também os escritores e críticos que defendiam:

o escritor haverá de alimentar-se a si próprio ou, quando muito, também de outros escritores. Mas nada tem que ir buscar à casa do psicólogo, do sociólogo, do historiador, do filósofo, que erram sempre, porque todas as doutrinas que explicam a vida são falsas, fanam-se na primeira volta do caminho do tempo (LIMA, 1948b, p. 17).

Este foi um dos aspetos que a nova geração mais criticou nos colaboradores da Presença. Em 1937, Armando Martins criticava a poesia do $e$ u de um dos nomes maiores da revista:

Régio é o poeta de si. Quase todos os seus versos cantam as baixezas e heroísmos banais do seu eu enorme (...) A poesia de Régio é uma casa fechada sem janelas para a rua; lá dentro, às escuras, um homem torce-se em combates e dores que não procuram a 
comunicação para se lavarem em amor humano (MARTINS, 1937b, p. 13).

Armando Martins divergia claramente de José Régio, embora lhe reconhecesse talento, mas lamentava as suas opções literárias: "É pena que um poeta de tanto talento não construa numa ânsia mais universal, vibrando nos seus versos, a inquietação do que é colectivo dentro de si, a angústia do Homem que quer atirar aos outros o seu abraço social" (ibidem). Reconhecia, também, diferenças entre os escritores e críticos da Presença, considerando que Casais Monteiro estava mais preocupado do que Régio com a comunicação social e com a fertilidade dos seus abraços de contacto humano (ibidem).

$\mathrm{Na}$ realidade, podemos dizê-lo, o que seria um dos objetivos mais constantes dos presencistas, como anota David Mourão Ferreira, era defender "uma criação e uma crítica livres, quanto possível, de circunstâncias de tempo e de espaço" (apud Soares, 1971, p. 22).

A jovem geração acusava, no entanto, a geração modernista antecedente de se afastar dos interesses coletivos e das realidades dos homens do seu tempo. Consideravam que a literatura se afastara dos interesses e das realidades humanas, acusando-a, por isso, de desumanização.

$\mathrm{Na}$ verdade, durante esta querela, alguns presencistas manifestavam posições bastante radicais: "desde que uma obra manifestasse preocupações de carácter social, ou ela fosse encarada ou criticada de um ponto de vista sociológico, já não pertenceria ao domínio da Literatura mas ao da Sociologia" (Torres, 1977, p. 48). Desta forma, segundo os presencistas, a conceção neorrealista de literatura faria com que esta perdesse autonomia; segundo os neorrealistas, ela seria apenas mais um fenómeno social e cultural.

A discussão caracterizou-se, de facto, tendencialmente, por acusações generalizadas e exageradas: tanto as acusações de arte-pela-arte, absolutamente pura e meramente formalista, por um lado, como as acusações de arte panfletária, ao serviço de uma ideologia política e que veiculava teses sociológicas e políticas, sem qualquer preocupação estética, por outro.

Dos confrontos teóricos, nasceu a acusação genérica e fácil de que toda a Presença estaria imbuída de umbilicalismo e de que os neorrealistas eram fanáticos e, sobretudo, dogmáticos (Torres, 1977, p. 55). No entanto, esta geração de 40, ao contrário das acusações que lhe iam sendo feitas, sempre procurou recusar todo o tipo de esquemas atrofiadores; sempre tendeu a procurar "novas aquisições para novas sínteses", vindo a acabar por ser, no fundo, "uma síntese entre aquilo que começou por ser e aquilo que lhe foi oposto", como bem observa Fernando Namora (1998, p. 282-283).

Os excessos que, inquestionavelmente, houve no momento inicial de afirmação do movimento deveram-se à necessidade de rutura com uma forma de ver o mundo e com uma específica conceção de arte. Ao nível do conteúdo, a rutura fez-se teórica e artisticamente de imediato; ao nível da forma, a evolução foi gradual, depurando-se artisticamente com o tempo. Recordemos o que viria a afirmar Alves Redol: "Tão aguerrida batalha pelo conteúdo em literatura parecia urgente 
a todos os jovens que ansiavam plantar os alicerces para um novo tipo de cultura extensiva às grandes massas ausentes da actual, preparando pelo alargamento à quantidade a síntese posterior da qualidade" (1993, p. 49).

Entre os presencistas, as posições mais extremadas não correspondiam às opiniões de todos os colaboradores da revista; todavia, consideravam, genericamente, que a teorização neorrealista era apoiada em princípios que se podiam aplicar à literatura, mas que veiculava ideias mais gerais, ideias sociológicas que fora do campo da literatura procuravam informá-la, moldá-la e encaminhá-la (Andrade, 2002, p. 46). Adolfo Casais Monteiro, o presencista que assumiu um papel conciliador nesta querela, afirmava ainda no final dos anos 30: "Se é certo haver qualidades que a arte não pode abandonar sem deixar de ser arte, não é menos certo haver quem se recuse a ver as razões reais e as reais exigências de uma arte em que o homem não apareça despegado da vida, isolado dos seus mais instantes problemas" (1939, p. 298).

Mais tarde um dos principais críticos da Presença, João Gaspar Simões, viria a dar razão aos neorrealistas e a admitir que o individualismo, nos política e socialmente desumanos anos 40, já não teria sido viável: "Já não era possível o individualismo que fora o fundamento das concepções presencistas", viria a reconhecer na segunda metade do século (1977, p. 195).

Deve também recordar-se que os próprios neorrealistas viriam a reconhecer que, por se oporem a uma literatura que consideravam excessivamente afastada dos problemas sociais do homem, "a reacção operou-se também por outro excesso, fenómeno natural no jogo das contradições", como escreveria Alves Redol (1993, p. 51). No fundo, tratava-se de algo em consonância com aquilo que Plekhanov dissera metaforicamente: "Quando um vime está torto num sentido, deve-se, para o endireitar, entortá-lo no sentido contrário" (1973, p. 11). É assim que, na nossa opinião, devem ser lidas algumas obras, em sintonia com a teorização que as precedeu, da fase inicial de rutura e afirmação do movimento neorrealista.

\section{BibLIOGRAFIA:}

ALMEIDA, António Ramos de. A Arte e a Vida. Porto: Livraria Latina Editora, 1945.

ANDRADE, João Pedro de. Ambições e Limites do Neo-Realismo Português. Lisboa: Acontecimento, 2002.

CARAÇA, Bento de Jesus. Cultura e realidade nacional, in O Diabo, $n^{\circ}$ 224, 7/1/1939, p 1, 1939. CARVALHO, Amorim de. O carácter social da arte, in O Diabo, nº 61, 25/04/1935, p. 2, 1935.

COELHO, Nelly Novaes. Fernando Namora: romance-testemunho da contemporaneidade. In Escritores Portugueses do Século XX. Lisboa: INCM, pp. 173-188, 2007.

DIONísIO, Mário. A propósito de Jorge Amado, in $O$ Diabo, $n^{\circ} 164,1937$, p. 3, 1937.

DIONÍSIO, Mário. S.O.S. geração em perigo, in O Diabo, Ano VI, nº 248, 24 de Junho de 1939, p. 12, 1939.

DIONÍSIO, Mário. Os Caminheiros e outros contos de José Cardoso Pires, in Vértice, vol. VIII, ${ }^{\circ}$ 76, 1949, pp. 368-369, 1949. 
FEIJÓ, Rui. Apontamentos sobre o neorealismo, in Seara Nova, 816, Lisboa, 1943, p. 319, 1943.

GRADIM, Rui. Significado filosófico da Física Moderna, in Vértice, vol. V, $\mathrm{n}^{\circ}$ 56-57, pp. 339346, 1948.

LIMA, Manuel Campos. Adolescentes de José Marmelo e Silva, in Vértice, vol. V, $\mathrm{n}^{\circ}$ 56-57, Abril-Maio de 1948, pp. 360-363, 1948a.

LIMA, Manuel Campos. Duas atitudes perante o conhecimento, in Seara Nova, 1084, pp. 17-19, 1948 b.

LOURENÇO, Eduardo. A ficção dos anos 40 ou o neo-realismo e o resto, in Jornal de Letras, Artes e Ideias, ano II, $\mathrm{n}^{\circ}$ 32, Maio de 1982, pp. 2-3, 1982.

LUKÁCS, Georges. Introdução a Uma Estética Marxista. Rio de Janeiro: Civilização Brasileira, 1978.

MARTINS, Armando. Novo tipo de mulher de Júlio Dantas e a nova mulher, in Sol Nascente, $n^{\circ}$ 9, 1/6/1937, pp. 12-13, 1937a.

MARTINS, Armando. José Régio - Casais Monteiro, poetas, In Sol Nascente, 20, 1/12/1937, Porto, p 13, 1937b.

MONTEIRO, Adolfo Casais. Introdução à leitura dos poetas modernos, in O Diabo, $\mathrm{n}^{\circ}$ 132, 3/1/1937, p. 8, 1937.

MONTEIRO, Adolfo Casais. Os problemas da arte são problemas da vida, in Seara Nova, 635, Lisboa, p. 298, 1939.

MONTEIRO, Adolfo Casais. Literatura e ideais de vida, in Seara Nova, XXVII, $n^{\circ} 1093$, de 2 de Out. de 1948, pp. 168-169, 1948.

MOURÃO-FERREIRA, David. Esta nova presença da Presença, in Presença - edição facsimilada compacta. Lisboa: Contexto, pp. 5-7, 1993.
NAMORA, Fernando. Em torno do neorealismo, in Um Sino na Montanha. Mem Martins: Europa-América, pp. 195-220, 1991.

NAMORA, Fernando. Carta aberta a Alves Redol, in A Nave de Pedra. Mem Martins: Europa-América, 1998.

NAMORADO, Joaquim. Prefácio-Homenagem a Políbio Gomes dos Santos. In SANTOS, Políbio Gomes dos. Voz Que Escuta, Colecção Novo Cancioneiro. Coimbra: Atlântida, 1944.

PITA, António Pedro. Conflito e Unidade no NeoRealismo Português. Porto: Campo das Letras, 2002.

\section{PLEKHANOV, G.. Ensaios sobre a História do} Materialismo. Lisboa: Editorial Estampa, 1973. REDOL, Alves. Prefácio - Breve memória, in Gaibéus. Lisboa: Caminho, 1993.

RÉGIO, José. Classicismo e modernismo, in Presença, $n^{\circ}$ 2, Coimbra, 28/03/1927, pp. 1-2, 1927.

RÉGIO, José. Comentário - interrogações e dúvidas sobre um depoimento de Rodrigues Miguéis, in Presença, $n^{\circ}$ 44, Abril de 1935, pp 12-14, 1935.

RÉGIO, José. Página indiscreta, in Presença, $n^{\circ} 1$, ano XII, série II, pp. 59-61, 1939.

RÉGIO, José. Mar de Sargaços, poemas por Fernando Namora; Em cada dia se morre, poemas por Tomaz Kim; Janela indiscreta, poemas por Leonel Neves, in Presença, $n^{\circ} 2$, ano XII, série II, pp. 121-124, 1940.

ROCHA, Clara. Revistas Literárias do Século XX em Portugal. Lisboa: INCM, 1985.

REIS, Carlos. O Discurso Ideológico do NeoRealismo Português. Coimbra: Almedina, 1983. RELVAS, Carlos. Serra-Mãe, de Sebastião da Gama, in Vértice, vol. II, fasc. 8, $\mathrm{n}^{\circ}$ 36-39, p. 197, 1946. 
SACRAMENTO, Mário. Fernando Namora. Lisboa: Arcádia, 1967.

SALEMA, Álvaro. Tempo de Leitura. Lisboa: Moraes, 1982.

SIMÕES, João Gaspar. Realidade e humanidade na arte, in Presença, nº 16, pp. 2-4, 1928.

SIMÕES, João Gaspar. Deformação - génese de toda a arte, in Presença, n 45, pp. 7-11, 1935. SIMÕES, João Gaspar. Breve esclarecimento a um ponto de vista sobre o romane brasileiro, in Presença, $n^{\circ} 1$, ano XII, série II, pp. 57-58, 1939. SIMÕES, João Gaspar. José Régio e a História do Movimento da "Presença". Porto: Brasília Editora, 1977.

SOARES, Fernando Luso. Algumas coordenadas da poesia de Fernando Namora, in Literatura, Dialéctica, Estrutura. Lisboa: Cronos, pp. 1781, 1971.

SOARES, Rodrigo. Por Um Novo Humanismo. Porto: Portugália, 1947.

TORRES, Alexandre Pinheiro. O Movimento Neo-Realista em Portugal na Sua Primeira Fase. Lisboa: Instituto de Cultura Portuguesa, 1977.

TORRES, Alexandre Pinheiro. Prefácio, in Novo Cancioneiro. Lisboa: Caminho, 1989.

TRINDADE, Luís. O Espírito do Diabo Discursos e Posições Intelectuais no Semanário “O Diabo”. Porto: Campo das Letras, 2004.

Recebido para publicação em 01 nov. 2016. Aceito para publicação em 12 jan. 2017. 